\title{
Activating the DNA Damage Response and Suppressing Innate Immunity: Human Papillomaviruses Walk the Line
}

\author{
Claire D. James ${ }^{1}$, Dipon Das ${ }^{1}$, Molly L. Bristol ${ }^{1}$ (I) and Iain M. Morgan ${ }^{1,2, *}$ \\ 1 Philips Institute for Oral Health Research, School of Dentistry, Virginia Commonwealth University (VCU), \\ Richmond, VA 23298, USA; cdjames@vcu.edu (C.D.J.); ddas@vcu.edu (D.D.); mlbristol@vcu.edu (M.L.B.) \\ 2 VCU Massey Cancer Center, Richmond, VA 23298, USA \\ * Correspondence: immorgan@vcu.edu; Tel.: +1-804-828-0149
}

Received: 30 April 2020; Accepted: 10 June 2020; Published: 13 June 2020

check for updates

\begin{abstract}
Activation of the DNA damage response (DDR) by external agents can result in DNA fragments entering the cytoplasm and activating innate immune signaling pathways, including the stimulator of interferon genes (STING) pathway. The consequences of this activation can result in alterations in the cell cycle including the induction of cellular senescence, as well as boost the adaptive immune response following interferon production. Human papillomaviruses (HPV) are the causative agents in a host of human cancers including cervical and oropharyngeal; HPV are responsible for around 5\% of all cancers. During infection, HPV replication activates the DDR in order to promote the viral life cycle. A striking feature of HPV-infected cells is their ability to continue to proliferate in the presence of an active DDR. Simultaneously, HPV suppress the innate immune response using a number of different mechanisms. The activation of the DDR and suppression of the innate immune response are essential for the progression of the viral life cycle. Here, we describe the mechanisms HPV use to turn on the DDR, while simultaneously suppressing the innate immune response. Pushing HPV from this fine line and tipping the balance towards activation of the innate immune response would be therapeutically beneficial.
\end{abstract}

Keywords: human papillomavirus; cervical cancer; head and neck cancer; DNA damage response; innate immune response; interaction

\section{Introduction}

Human papillomaviruses activate the DNA damage response and suppress innate immunity, two processes that are required for a successful viral life cycle [1-6]. There is a link between these two pathways in non-HPV cells; DNA damage can induce the innate immune response, resulting in interferon production and potential attenuation of cellular proliferation [7-12]. Figure 1 summarizes how HPV can activate the DDR, including via replication stress on the replicating viral DNA. This replication stress could result in the production of DNA fragments that could egress to the cytoplasm and activate the innate immune response (Figure 2). To combat this, HPV have multiple mechanisms for repressing the innate immune response (Figure 3). The purpose of this review is to reflect on how HPV manipulate these two pathways to allow progression of the viral life cycle, and to highlight some known interactions between the two pathways regulated by HPV. Inhibition of the DDR blocks the HPV life cycle and is a strategy for controlling infection and treating cancers. Similarly, activating innate immunity, while not disrupting HPV activation of the DDR, could be a useful therapeutic tool for combating HPV disease. We will begin the review by describing the activation and manipulation of the DDR by HPV. How HPV regulate the innate immune response will 
follow. Finally, we will highlight interactions between the DDR and innate immunity in HPV cells mediated by the viral replication complex.

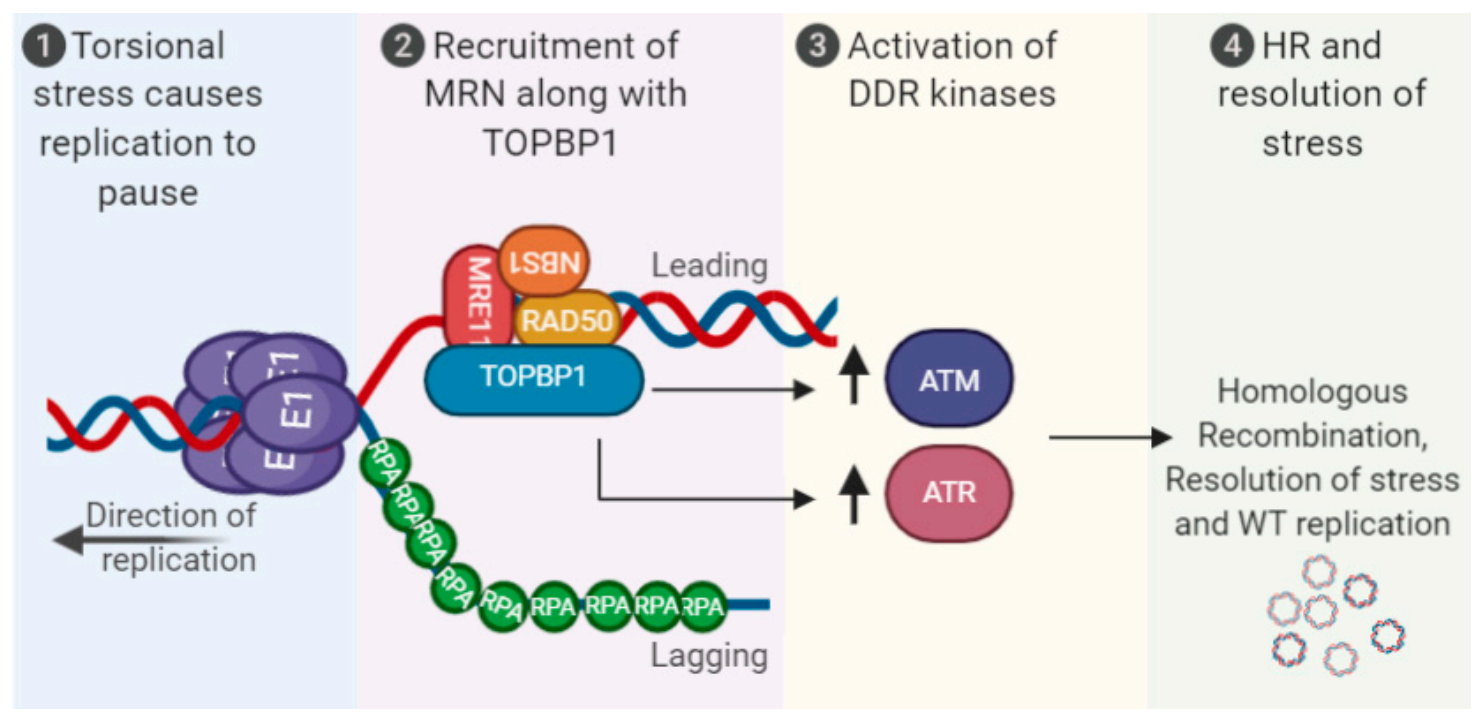

Figure 1. Activation of the DNA damage response (DDR) via human papillomaviruses (HPV) replication stress. Torsional stress on the replicating $8 \mathrm{kbp}$ genome results in replication pausing, recruitment of MRN along with TopBP1 and associated proteins. This promotes activation of the DDR kinases ATR/ATM and homologous recombination (HR) resolution of the stress to promote high-fidelity viral replication. The viral oncogenes E6 and E7 can also induce the DDR, and replication stress, see text for details. MRN (MRE11-RAD50-NBS1).

\section{The DDR during the HPV Life Cycle}

Papillomaviruses are divided into low-risk (LR) and high-risk (HR) types, with the criteria for HR-HPV types being that they cause cancer [13]. This review focuses on HR-HPV, and henceforth "HPV" refers to HR-HPV. HPV infect basal cells of the epithelium via abrasions that allow access for viral particles $[6,14,15]$. Following infection, HPV must wait for mitosis in order for the virus to enter the nucleus and begin the viral life cycle $[16,17]$. Once located to the nucleus, transcription occurs from the viral long control region (LCR), mediated by host cellular factors [18]. This results in a transcript processed into RNA species that are translated to produce the viral proteins. The HPV oncoproteins E6 and E7 target a host of cellular proteins, including p53 and pRb, respectively. These oncoproteins promote proliferation of the infected cell and protect it from growth attenuation, therefore promoting the viral life cycle [19-23]. Two viral proteins, E1 and E2, are required for replication of the viral genome in association with host proteins [24-26]. E2 is a DNA binding factor that forms homodimers and binds to specific $12 \mathrm{bp}$ palindromic sequences in the LCR that surround an A/T-rich origin of replication [27]. Following binding to its target sequences, E2 recruits the viral helicase E1 that forms a di-hexameric complex responsible for replicating the viral genome in association with host polymerases $[28,29]$. Following the initiation of replication in the infected cell, the viral genome copy number establishes at multiple copies per cell. As the proliferating infected cell moves through the epithelium, the copy number is maintained. In the upper layers of the epithelium, an amplification stage increases the viral genome copy number in a population of the differentiated cells. At this stage of the viral life cycle, the viral structural proteins L1 and L2 encapsulate the viral genomes, forming viral particles. These viral particles then egress from the top layer of the differentiated epithelium. 


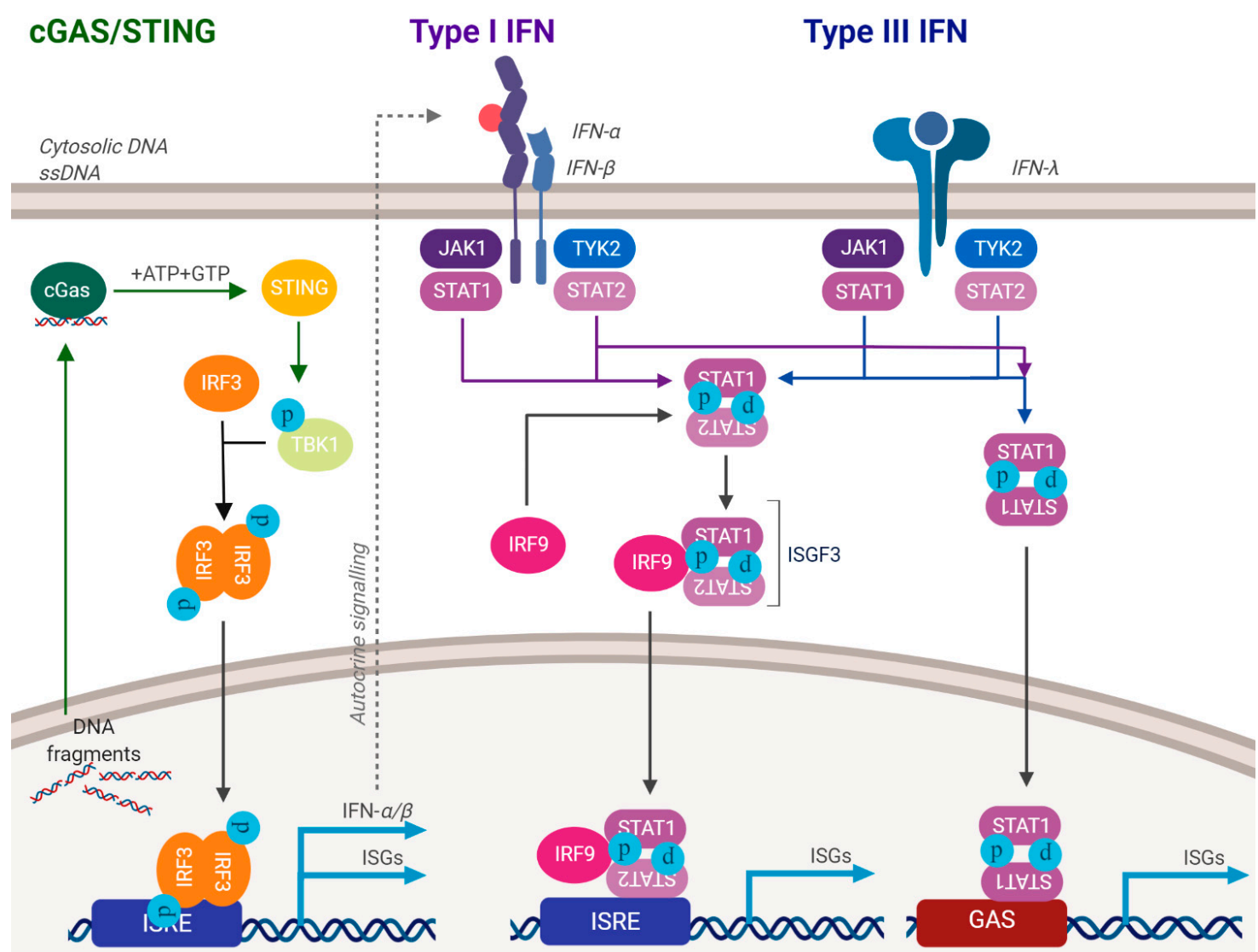

Figure 2. Activation of the innate immune response. DNA damaging agents and/or aberrant release of DNA fragments into the cytoplasm can activate the innate immune response. This can often attenuate cellular growth. As HPV activate the DDR, they must suppress the innate immune response. See text for details.

During the establishment phase of the viral life cycle, the amplification of the viral genome from one to multiple copies per cell likely activates the DDR due to torsional stress on the viral genome caused by clashing replication forks [30]. Three viral proteins can activate the DDR when expressed in isolation: E1, E6 and E7. E1 binds cellular DNA indiscriminately, activating DNA unwinding and replication via its helicase activity and interaction with cellular polymerases [31-35]. E1, and its binding partner E2, require interactions with host DNA replication factors and DDR proteins to carry out viral replication [36-39]. The E1 expression alone induces various DNA damage markers, likely due to its helicase activity; moreover, E1-E2-containing viral replication foci co-localize with various DDR markers and confer replication fidelity [40,41].

E6 targets p53 for degradation, therefore altering the cellular response to DNA damage; p53 is integral to a healthy response to DNA damage in order to promote cell cycle arrest followed by DNA repair, or apoptosis to kill the damaged cell [21]. E7 disrupts the function of the tumor suppressor $\mathrm{pRb}$ in order to promote the transition from the G1 to $S$ phase [19]. In addition, E7 disrupts several processes during mitosis that can result in genomic instability and the combined functions of E7 stimulate activation of the DDR [42-45]. These studies employed overexpression of viral proteins, and monitored their effect on the cell and the DDR pathway. We recently reported that HPV16 activates the DDR in human keratinocytes irrespective of the expression of E6 and E7 (Figure 4) [46]. This was done by introducing stop codons into the E6 and E7 genes (individually and combined) in the full HPV16 genome and generating N/Tert- 1 (human foreskin keratinocytes immortalized by telomerase) cells containing wild type and mutant genomes. N/Tert-1 cells support late stage markers of the HPV16 life cycle and are transcriptionally reprogrammed by the virus $[47,48]$. Strikingly, the DDR 
activation and the upregulation of replication stress response genes were identical in the N/Tert-1 cells with HPV16 genomes irrespective of mutations in E6 or E7, or in both. This demonstrates that viral replication per se likely directly activates the DDR and this is logical based on the challenge viral replication poses to the cells when establishing 20-50 copies per cell during the initial infection. Clearly, activation of the DDR by viral replication has the potential to attenuate cellular growth and this is what we observed in our N/Tert-1 system; N/Tert-1 cells expressing the HPV16 genome that lacked the expression of E6 and E7 grew significantly slower than those containing the intact HPV16 genome. Therefore, the viral oncogenes E6 and E7 overcome the DDR originating from viral genome replication that suppresses cell growth in order to promote proliferation. This is supported by the observation that in the presence of the E6 and E7 oncogenes, the DNA damage response is manipulated and host DNA repair factors have an aberrant interaction with the host chromatin [49]. This potentially prevents the host genome "seeing" the DDR signals sent from viral replication. This is likely why, when overexpressed by themselves, E6 and E7 activate the DDR; their manipulation of DNA damage and repair factors away from the host genome would provide replication stress that would activate the DDR. A number of DNA damage and repair proteins interact with replicating viral DNA and promote homologous recombination (HR) repair on the replicating viral DNA [39,41,50-57]. This would repair stalled and broken replication forks and allow high-fidelity replication of the viral genome.

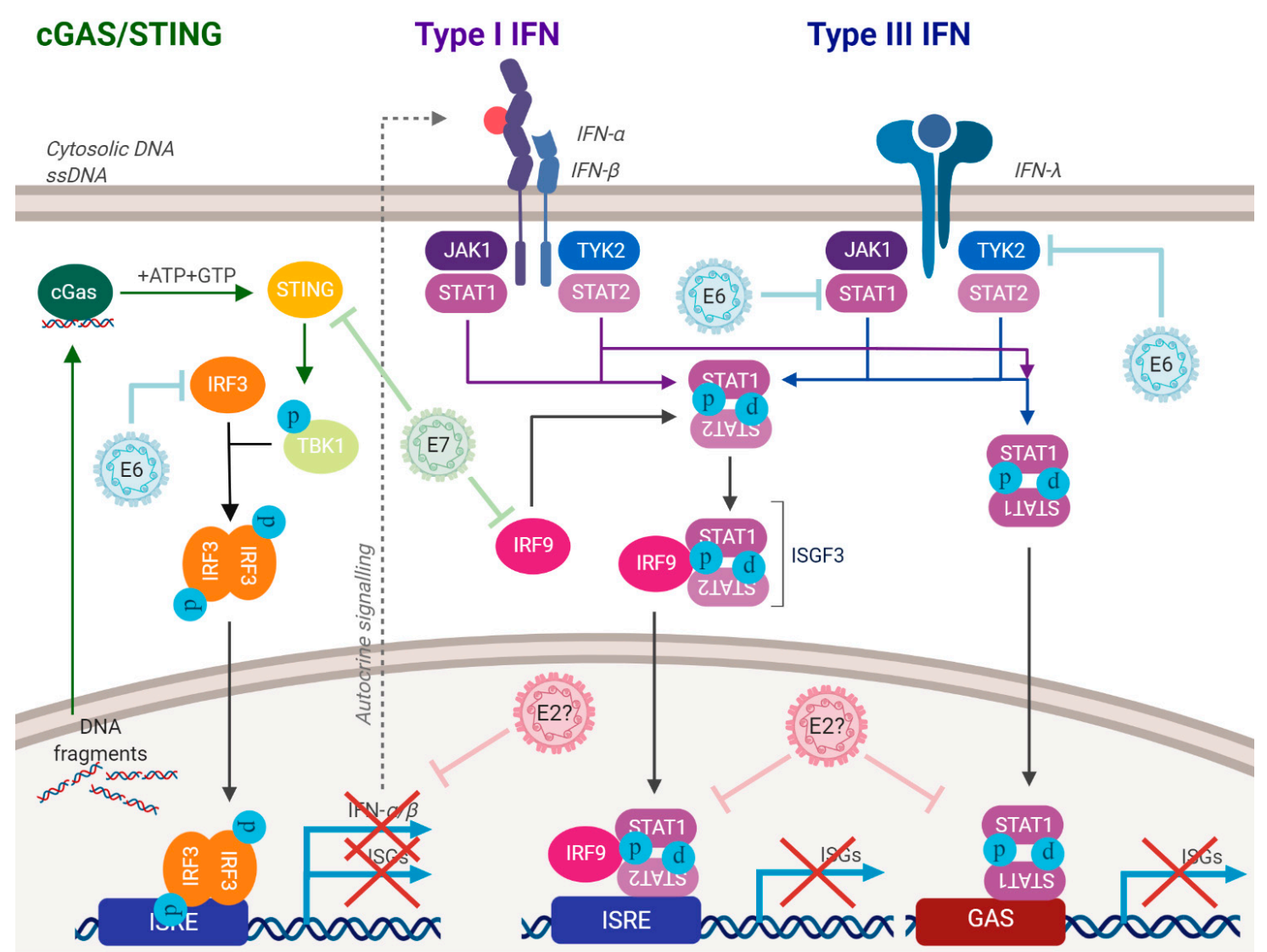

Figure 3. HPV have multiple mechanisms for suppressing the innate immune response. E6 and E7 can repress the innate immune response pathways, some of their mechanisms have been identified. E2 can also repress the innate immune response, but the mechanism is unknown. E5 can also regulate the innate immune response. These processes allow HPV-infected cells to progress through the cell cycle with an activated DDR. This repression also blocks the production of interferon. See text for details. 


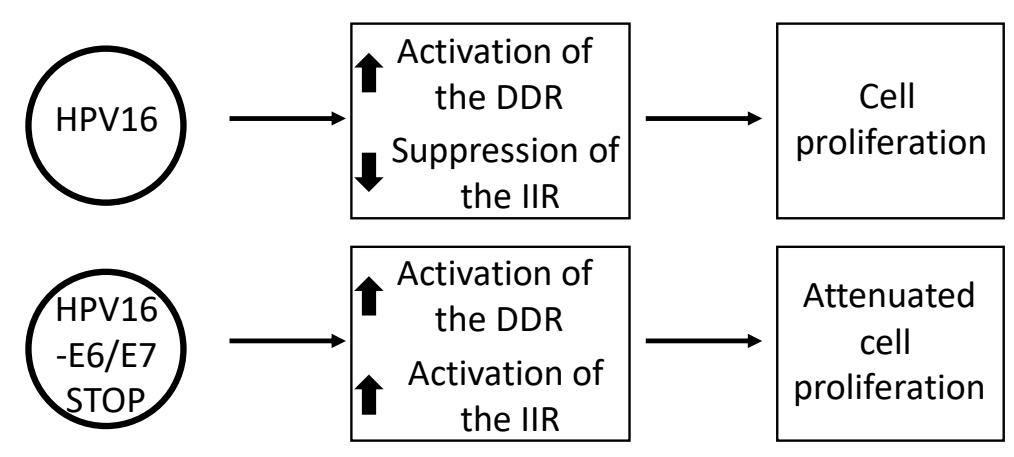

Figure 4. HPV16 E6 and E7 are required for the suppression of the innate immune response (IIR). N/Tert-1 cells (TERT immortalized foreskin keratinocytes) containing an episomal, intact HPV16 genome have an activated DDR and a repressed IIR. However, a stop codon in either E6 or E7 blocks the repression of the IIR and if the expression of both oncogenes is blocked, this significantly attenuates cell growth.

In 2009, Moody and Laimins published a seminal paper demonstrating activation of the DDR by HPV31 in keratinocytes, and that this activation is required for the amplification stage of the viral life cycle [58]. The addition of ATM inhibitors blocked amplification of the viral genome following differentiation of HPV31 containing human keratinocytes. ATM inhibition did not affect maintenance of the viral genomes in monolayer cells. This report also demonstrated that overexpression of E7 by itself can induce the DDR and that E7 and ATM form a cellular complex. Overexpression of E7 can induce increased expression of several proteins involved in DNA replication and repair [59]. Many of the genes encoding these proteins are targets of $\mathrm{E} 2 \mathrm{~F} 1$, a protein regulated by $\mathrm{pRb}$, a primary target of E7. Subsequent studies demonstrated that a number of host DDR proteins are recruited to HPV replication foci, presumably to facilitate HR-mediated viral DNA replication [41,52-56]. The knock down of several of these factors results in abrogation of the viral genome amplification; in particular, the MRN complex (MRE11-RAD50-NBS1) is crucial in this regard [53]. The MRN complex recognizes double-stranded DNA breaks and is required for efficient HR in human cells. Indeed, BRCA1 and RAD51, two proteins required for processing DNA for efficient $H R$, also are required for amplification of HPV DNA during differentiation of human keratinocytes [52].

Completion of the viral life cycle requires a complex interaction between HPV and the DDR. This interaction allows the proliferation of infected cells with an active DDR, something that ordinarily should not occur. External DNA-damaging agents cause cell cycle arrest, a pause that allows for recognition of the damage, its repair and subsequent re-entry into the cell cycle [60]. Therefore, the DDR turned on by HPV, which initiates internally in the cell, represents a unique activation of the DDR pathway that is a therapeutic target in HPV-positive cells.

\section{HPV and Repression of the Innate Immune Response (IIR)}

Viral infection is met with a host of defense mechanisms in mammalian cells, and these can target HPV infection. Before discussing the evasion strategies HPV use against these host defense mechanisms, we will briefly introduce the innate immune response. Mammalian cells express cytoplasmic proteins that act as pathogen recognition receptors (PRRs), responsible for recognizing external agents such as RNA and DNA viruses [61]. PRRs then activate a host of cellular response pathways. External DNA-damaging agents can also activate the innate immune response in treated cells, due to fragments of damaged DNA escaping from the nucleus into the cytoplasm [12]. A major pathway activated by recognition of cytoplasmic DNA is the stimulator of interferon genes (STING) pathway [62]. cGAS is the cytoplasmic sensor in the STING pathway; activation of cGAS results in the production of the second messenger GMP-AMP (cGAMP) [63]. cGAMP then interacts with the STING protein on the endoplasmic reticulum, promoting its translocation to the Golgi. This results in recruitment of TANK-binding kinase 1 (TBK1) and IKB kinase (IKK) which phosphorylate interferon regulatory factor 
3 (IRF3) and the NF- $\mathrm{B} B$ inhibitor I $\mathrm{KB} \alpha$, respectively [64]. IRF3 then dimerizes and enters the nucleus, resulting in transcriptional activation of genes encoding type 1 interferons. I $\kappa B \alpha$ phosphorylation results in NF-KB nuclear entry and activation of the transcription of pro-inflammatory cytokines including IL6 and TNF. Overall, PRRs activate innate immunity, which in turn assists with the activation of adaptive immunity.

HPV have evolved multiple mechanisms for suppressing the IIR. This is likely because HPV genomes are relatively small DNA molecules replicating more than once per cell cycle and could produce DNA fragments that could egress to the cytoplasm and activate the IIR. The consequences of not repressing the IIR, would be a downregulation of cellular proliferation or the induction of senescence that would disrupt the viral life cycle. Lau and colleagues demonstrated that HPV E7 binds to STING and prevents its signaling, therefore preventing the production of interferon [65]. Moreover, E6 can complex with IRF3 and inhibit its transcription activity which would also compromise the STING pathway [66]. Much work remains in order to enhance our understanding of how HPV regulate STING during the viral life cycle.

Interferon (class 1) activates the transcription of interferon-stimulated genes (ISGs) via a transcription complex called interferon stimulated gene factor 3 (ISGF3) [67-69]. This complex consists of STAT1 and STAT2, phosphorylated via interferon signaling by Janus kinases (JAK), that then complex with IRF9 and enter the nucleus to bind specific DNA sequences and activate the transcription of ISGs $[70,71]$. Following viral infection, there is residual unphosphorylated ISGF3 (UISGF3) activity that results in a longer-term activation of a sub-set of ISGs, thought to act as an innate "memory" that can deal quickly with a subsequent viral infection [72]. Interestingly, long-term exposure of cells to IFN- $\beta$ results in elevated levels of these ISGs, but also results in resistance to DNA-damaging agents as well as to viruses, providing a further link between the DDR and IIR [73]. Given the anti-viral nature of ISGs, HPV have multiple mechanisms for blocking the JAK-STAT pathway to prevent their activation of ISGs. Four viral proteins, when overexpressed, can repress ISG expression: E6, E7, E1 and E2 $[20,47,74,75]$.

E6 and E7 block interferon signaling at precise points in the pathway. E6 binds to Tyk2 to impair Jak-STAT activation by IFN $\alpha$, and also promotes resistance to interferon-induced growth arrest via inhibition of p53 acetylation [76,77]. This repression of the innate immune system by HPV promotes the viral life cycle via the subversion of host immunity, but downregulation of STAT-1 is also required for amplification of the viral genome during the HPV life cycle, and there is also a role for STAT5 in this process [78-80].

What is the main viral protein that represses the innate immune system, and does this change during the viral life cycle? We began to address this question using our N/Tert-1 system that contained wild type and E6/E7 mutant genomes. To our surprise, elimination of the expression of either oncogene completely relieved the repression of innate immune genes by HPV16 [46]. Therefore, even though overexpression of E6 or E7 by themselves in N/Tert-1 cells represses the expression of innate immune genes, both oncoproteins are required for this repression in the context of the entire HPV16 genome. One notable feature of the cells containing HPV16 genomes with stop codons in both E6 and E7 was that they grew more slowly than cells containing the wild type HPV16 genome. Furthermore, the expression of IFNK was elevated when compared with control and other HPV16 genome-containing cells. The mechanism for this increase in IFNk production is unclear, and differences in STING signaling in the E6 and E7 mutant genome cells were not easily detectable. Therefore, E6 and E7 relieve growth suppression induced by E1-E2 replication stress; IIR suppression may contribute to this process. In addition, the cellular protein IFIT1, which is repressed by HPV at the transcription level, can bind directly to HPV18 E1 and has the potential to attenuate HPV18 DNA replication [81,82]. Thus, downregulation of the IFIT1 expression is likely required for the HPV18 life cycle. A more recent study has also clearly demonstrated an essential role for E5 in the repression of innate immunity during the HPV16 life cycle, adding to the multifaceted story of how HPV16 represses innate immunity [83]. Overall, there are five viral proteins that can repress innate immunity (E6, E7, E1, E2 and E5), i.e., 
almost all the viral proteins expressed during the initial phase of infection. While this is complex, the good news from a therapeutic perspective is that targeting the E5, E6 or E7 mechanism may be sufficient to reactivate the innate immune response in HPV16 containing keratinocytes.

\section{Crosstalk between HPV DNA Replication, the DDR, and Innate Immunity}

Treatment of cells with drugs such as etoposide results in activation of the IIR, presumably due to disrupted replication producing small DNA fragments that enter the cytoplasm and are bound by PRRs [12]. Multiple viral proteins regulate the DDR (E6, E7, E1, E2 in association with E1) and all of these repress innate immune gene expression along with E5. Much work remains to resolve this complicated network of interactions between innate immunity and the DDR in the context of the HPV16 life cycle. There is a further viral process that crosstalks between the DDR and IIR, and that is viral DNA replication.

In an HPV-infected cell, high-fidelity host and viral replication are essential to block the release of DNA into the cytoplasm that could trigger the IIR. One way that the virus promotes fidelity of its own replication is to recruit DNA repair factors to the viral genome, where they facilitate homologous recombination (HR)-mediated DNA replication [41,50,52,53]. The MRN complex is recruited to the viral genome. This complex consists of MRE11, RAD50 and NBS1, and following double strand DNA breaks (DSBs), this complex recognizes the DNA damage and binds to the DNA [84]. Following binding to the DSB, the MRN complex slides 100-200 bp away from the broken end. MRE11 then performs an endonuclease cut in the DNA on the strand that has the $5^{\prime}$ free end on the DSB, assisted by another cellular protein, CtIP [85]. The MRN complex then moves back towards the broken edge where MRE11 3' to 5' exonuclease activity digests the nucleotides, leaving a 3' overhang strand on the strand not cut by MRE11 [86]. The MRN complex then detaches from the DSB. Additional exonucleases (such as Exo1 and DNA2) extend the 3' overhang on the DSB DNA [87,88]. This overhang is around $1000 \mathrm{bp}$ long and is protected by Replication Protein A (RPA) [89]. BRCA2-RAD51 then displace RPA forming a RAD51 ssDNA nucleofilament required for HR [90]. The RAD51 bound DNA then promotes strand invasion, ultimately resulting in HR repair of the broken DNA [91]. The recruitment of the MRN complex promotes activation of the DDR as NBS1 complexes with ATM and activates its activity following MRN binding to DSB DNA [92].

A striking feature of the MRN complex and RAD51 is that they are also a part of the innate immune system. MRE11 acts as a cytosolic sensor of double-stranded DNA (dsDNA) in association with RAD50 (NBS1 is not involved) and cells lacking MRE11-RAD50 have defects in dsDNA-induced type 1 IFN production [93]. This is because MRE11-RAD50 is required for activation of STING and IRF3. Defects in RAD51 result in an accumulation of host DNA in the cytoplasm, which stimulates the STING pathway, resulting in downstream activation of IFN production [94]. Therefore, it is possible that the recruitment of MRN and RAD51 to the viral genome is another defense against innate immunity, simultaneously preventing MRE11-RAD50 localization to the cytoplasm, and inappropriate processing of host DNA by RAD51 when the MRN complex is disrupted by viral infection. Therefore, in addition to the roles that the viral proteins play in downregulating the IIR, viral DNA replication may control innate immunity by recruiting these DNA damage and repair proteins to the viral genome. In addition, the disruption by E6/E7 of host repair functions would also prevent processing of host DNA that could generate DNA fragments that would otherwise egress to the cytoplasm and activate the IIR [49].

Recently we demonstrated that the ISG SAMHD1 (sterile alpha motif and HD-domain containing protein 1) is transcriptionally downregulated by HPV16 [47]. SAMHD1 is at the crossroads of innate immunity and DNA replication/damage [95]. It is often mutated in Aicardi-Goutieres syndrome (AGS), a rare Mendelian disorder that has a constitutively active cGAS-STING pathway and increased interferon production [95]. SAMHD1 is a restriction factor for HIV-1 infection and encodes dNTP hydrolase enzyme activity [96-102]. In G1, SAMHD1 forms a tetramer that has hydrolase activity to regulate the dNTP pool. Following cell cycle progression into the $S$ phase, SAMHD1 is phosphorylated by CycA-CDK and this attenuates the dNTPase activity, providing increased cellular dNTPs during 
the S phase [103]. SAMHD1 also functions as an important DDR factor that assists with HR repair of double-stranded DNA breaks [104-108]. It stimulates the $3^{\prime}$ to $5^{\prime}$ exonuclease activity of MRE11 and therefore works at the double strand break with the MRN complex to prevent interferon production [106,108]. As well as regulating HIV1, SAMHD1 regulates the life cycles of several DNA viruses [109-111]. What is the role of SAMHD1 during the HPV16 life cycle? CRISPR removal of SAMHD1 results in an aberrant life cycle with enhanced cellular proliferation and viral DNA replication and DNA damage [112]. SAMHD1 is phosphorylated in HPV16-positive cells, switching off the hydrolase activity and potentially promoting its role in DSB repair (James and Morgan, unpublished). Interestingly, the role of SAMHD1 in DNA repair is independent from its hydrolase activity [106]. The role of SAMHD1 in HR is to promote binding of CtIP with the MRN complex, boosting the enzyme activity of MRE11 during HR [106]. Therefore, when we remove SAMHD1 from HPV16-positive cells, the increased DNA damage and cell proliferation is likely due to the aberrant processing of HPV16 DNA during the viral life cycle. We have already demonstrated recruitment of SAMHD1 to the viral genome during replication (James, Das and Morgan, unpublished) and are currently investigating the precise role for SAMHD1 during HPV16 DNA replication. Others have shown that SAMHD1 depletion creates genomic instability and activation of DNA damage signaling which stimulates the innate immune response [107]. Therefore, the interaction between HPV16 and SAMHD1 occurs at a direct crossover between the DDR and the IIR.

Recently we demonstrated that the Werner helicase (WRN) is a member of the HPV16 DNA replication complex [55]. Mutations in WRN result in Werner syndrome; patients with this syndrome have premature aging and a predisposition to cancers $[113,114]$. CRISPR removal of WRN results in elevated E1-E2 DNA replication levels that are of a poorer quality. As with SAMHD1, WRN is mutated in AGS; the mutation frequencies differ, but the link is intriguing [115]. WRN is a nucleolar protein that enters the nucleoplasm following DNA damage and then interacts with damaged DNA [116]. It is a member of the RecQ family of helicases (operating in a $3^{\prime}$ to $5^{\prime}$ direction) and has a $3^{\prime}$ to $5^{\prime}$ exonuclease activity [117]. WRN is involved in maintaining and repairing DNA replication forks following DNA damage [118-121]. Providing a further link to HPV replication, the WRN exonuclease domain protects DNA from pathological MRE11/EXO1-dependent degradation [122]. In summary, SAMHD1 and WRN both have direct roles in regulating the MRN complex. Both are involved in regulating the HPV life cycle and it is likely that they both have a critical role in interfacing between DNA replication and damage and suppression of the IIR. Like SAMHD1, depletion of WRN results in the aberrant processing of DNA DSBs and this could result in cytoplasmic accumulation of DNA that would activate the STING pathway to produce interferon [122-124]. The disruption of SAMHD1 and WRN function by HPV16 could recruit these proteins to the viral genome and prevent their processing of host DNA damage that could result in the production of cytoplasmic DNA.

\section{Conclusions and Future Perspectives}

This review summarizes our understanding of the HPV components regulating the DDR and IIR. Several factors during the viral life cycle target both functions to some degree. The regulation of the DDR by E6, E7 and E1 is well established, and E2 contributes by activating viral DNA replication in association with E1. E2 binds to several host proteins involved in the DDR and therefore could contribute directly to DDR regulation. Our recent demonstration that HPV16 genomes activate the DDR independently from E6 and E7 expression demonstrates that viral replication likely contributes to activation of the DDR. Indeed, we could see no difference in the DDR between cells with wild type viral genomes and those that lacked expression of E6 and E7. Overexpression of E6, E7, E2 and E1 can all repress the IIR. However, another striking observation from our recent paper is that disruption of E6 or E7 expression blocks the ability of HPV16 to suppress the IIR. HPV16 genomes with stop codons in E5 also result in activation of the IIR. Importantly, E6 or E7 disruption did not substantially alter the DDR in the HPV16-containing cells. Reactivating the IIR in cells with a persistent DDR could boost the IIR; in HPV16-containing cells, activation of the IIR is enhanced in the absence of E6 or E7 
when compared with control cells lacking HPV16. This result opens the therapeutic option of blocking the ability of E6, E7 or E5 (and perhaps E1 and E2) to suppress the IIR. Reactivation of host innate immunity in the infected cells would assist with the adaptive immune response to HPV-infected cells, and potentially boost immunotherapy treatments for HPV cancers.

Author Contributions: C.D.J., D.D., M.L.B. and I.M.M. conceived and wrote the manuscript. All authors have read and agreed to the published version of the manuscript.

Acknowledgments: This work was sponsored by grant P30 CA016059 from the National Cancer Institute. We apologize to colleagues if we have not cited their important work, this is a large field of research and on occasion, we have used reviews to provide the reader with an entry into certain fields.

Conflicts of Interest: The authors declare no conflict of interest.

\section{References}

1. Spriggs, C.C.; Laimins, L. Human Papillomavirus and the DNA Damage Response: Exploiting Host Repair Pathways for Viral Replication. Viruses 2017, 9, 232. [CrossRef] [PubMed]

2. Galloway, D.A.; Laimins, L. Human papillomaviruses: Shared and distinct pathways for pathogenesis. Curr. Opin. Virol. 2015, 14, 87-92. [CrossRef] [PubMed]

3. Hong, S.; Laimins, L. Regulation of the life cycle of HPVs by differentiation and the DNA damage response. Future Microbiol. 2013, 8, 1547-1557. [CrossRef] [PubMed]

4. Moody, C.A.; Laimins, L. Human papillomavirus oncoproteins: Pathways to transformation. Nat. Rev. Cancer 2010, 10, 550-560. [CrossRef]

5. Beglin, M.; Melar-New, M.; Laimins, L.A. Human Papillomaviruses and the Interferon Response. J. Interferon Cytokine Res. 2009, 29, 629-635. [CrossRef]

6. Doorbar, J.; Quint, W.; Banks, L.; Bravo, I.G.; Stoler, M.; Broker, T.R.; Stanley, M.A. The Biology and Life-Cycle of Human Papillomaviruses. Vaccine 2012, 30 (Suppl. 5), F55-F70. [CrossRef]

7. Bednarski, J.J.; Sleckman, B.P. At the intersection of DNA damage and immune responses. Nat. Rev. Immunol. 2019, 19, 231-242. [CrossRef]

8. Nakad, R.; Schumacher, B. DNA Damage Response and Immune Defense: Links and Mechanisms. Front. Genet. 2016, 7, 1065. [CrossRef]

9. Paludan, S.R.; Bowie, A.G. Immune sensing of DNA. Immunity 2013, 38, 870-880. [CrossRef]

10. Paludan, S.R. Activation and Regulation of DNA-Driven Immune Responses. Microbiol. Mol. Biol. Rev. 2015, 79, 225-241. [CrossRef]

11. Ermolaeva, M.; Schumacher, B. The innate immune system as mediator of systemic DNA damage responses. Commun. Integr. Biol. 2013, 6, e26926. [CrossRef] [PubMed]

12. Brzostek-Racine, S.; Gordon, C.; Van Scoy, S.; Reich, N.C. The DNA damage response induces IFN. J. Immunol. 2011, 187, 5336-5345. [CrossRef] [PubMed]

13. Hausen, H.Z. Papillomaviruses in the causation of human cancers-A brief historical account. Virology 2009, 384, 260-265. [CrossRef] [PubMed]

14. Schiffman, M.; Doorbar, J.; Wentzensen, N.; De Sanjose, S.; Fakhry, C.; Monk, B.J.; Stanley, M.A.; Franceschi, S. Carcinogenic human papillomavirus infection. Nat. Rev. Dis. Prim. 2016, 2, 16086. [CrossRef] [PubMed]

15. Stanley, M.A.; Pett, M.; Coleman, N. HPV: From infection to cancer. Biochem. Soc. Trans. 2007, 35, 1456-1460. [CrossRef] [PubMed]

16. Calton, C.M.; Bronnimann, M.P.; Manson, A.R.; Li, S.; Chapman, J.A.; Suarez-Berumen, M.; Williamson, T.R.; Molugu, S.K.; Bernal, R.A.; Campos, S.K. Translocation of the papillomavirus L2/vDNA complex across the limiting membrane requires the onset of mitosis. PLoS Pathog. 2017, 13, e1006200. [CrossRef]

17. DiGiuseppe, S.; Luszczek, W.; Keiffer, T.R.; Bienkowska-Haba, M.; Guion, L.G.M.; Sapp, M. Incoming human papillomavirus type 16 genome resides in a vesicular compartment throughout mitosis. Proc. Natl. Acad. Sci. USA 2016, 113, 6289-6294. [CrossRef]

18. Thierry, F. Transcriptional regulation of the papillomavirus oncogenes by cellular and viral transcription factors in cervical carcinoma. Virology 2009, 384, 375-379. [CrossRef]

19. Roman, A.; Munger, K. The papillomavirus E7 proteins. Virology 2013, 445, 138-168. [CrossRef] 
20. Songock, W.K.; Kim, S.-M.; Bodily, J. The human papillomavirus E7 oncoprotein as a regulator of transcription. Virus Res. 2017, 231, 56-75. [CrossRef]

21. Hoppe-Seyler, K.; Bossler, F.; Braun, J.A.; Herrmann, A.L.; Hoppe-Seyler, F. The HPV E6/E7 Oncogenes: Key Factors for Viral Carcinogenesis and Therapeutic Targets. Trends Microbiol. 2018, 26, 158-168. [CrossRef] [PubMed]

22. Mittal, S.; Banks, L. Molecular mechanisms underlying human papillomavirus E6 and E7 oncoprotein-induced cell transformation. Mutat. Res. Mutat. Res. 2017, 772, 23-35. [CrossRef] [PubMed]

23. White, E.A. Manipulation of Epithelial Differentiation by HPV Oncoproteins. Viruses 2019, 11, 369. [CrossRef] [PubMed]

24. Yasugi, T.; Benson, J.D.; Sakai, H.; Vidal, M.; Howley, P.M. Mapping and characterization of the interaction domains of human papillomavirus type 16 E1 and E2 proteins. J. Virol. 1997, 71, 891-899. [CrossRef] [PubMed]

25. Sakai, H.; Yasugi, T.; Benson, J.D.; Dowhanick, J.J.; Howley, P.M. Targeted mutagenesis of the human papillomavirus type 16 E2 transactivation domain reveals separable transcriptional activation and DNA replication functions. J. Virol. 1996, 70, 1602-1611. [CrossRef]

26. Benson, J.D.; Howley, P.M. Amino-terminal domains of the bovine papillomavirus type 1 E1 and E2 proteins participate in complex formation. J. Virol. 1995, 69, 4364-4372. [CrossRef]

27. McBride, A.A. The Papillomavirus E2 proteins. Virology 2013, 445, 57-79. [CrossRef] [PubMed]

28. Masterson, P.J.; Stanley, M.A.; Lewis, A.P.; Romanos, M.A. A C-Terminal Helicase Domain of the Human Papillomavirus E1 Protein Binds E2 and the DNA Polymerase $\alpha$-Primase p68 Subunit. J. Virol. 1998, 72, 7407-7419. [CrossRef]

29. Bergvall, M.; Melendy, T.; Archambault, J. The E1 proteins. Virology 2013, 445, 35-56. [CrossRef]

30. Bristol, M.L.; Das, D.; Morgan, I.M. Why Human Papillomaviruses Activate the DNA Damage Response (DDR) and How Cellular and Viral Replication Persists in the Presence of DDR Signaling. Viruses 2017, 9, 268. [CrossRef]

31. Sakakibara, N.; Mitra, R.; McBride, A.A. The Papillomavirus E1 Helicase Activates a Cellular DNA Damage Response in Viral Replication Foci. J. Virol. 2011, 85, 8981-8995. [CrossRef] [PubMed]

32. Fradet-Turcotte, A.; Bergeron-Labrecque, F.; Moody, C.A.; Lehoux, M.; Laimins, L.A.; Archambault, J. Nuclear Accumulation of the Papillomavirus E1 Helicase Blocks S-Phase Progression and Triggers an ATM-Dependent DNA Damage Response. J. Virol. 2011, 85, 8996-9012. [CrossRef] [PubMed]

33. Reinson, T.; Toots, M.; Kadaja, M.; Pipitch, R.; Allik, M.; Ustav, E.; Ustav, M. Engagement of the ATR-Dependent DNA Damage Response at the Human Papillomavirus 18 Replication Centers during the Initial Amplification. J. Virol. 2012, 87, 951-964. [CrossRef] [PubMed]

34. Kadaja, M.; Isok-Paas, H.; Laos, T.; Ustav, E.; Ustav, M. Mechanism of Genomic Instability in Cells Infected with the High-Risk Human Papillomaviruses. PLoS Pathog. 2009, 5, e1000397. [CrossRef] [PubMed]

35. Kadaja, M.; Sumerina, A.; Verst, T.; Ojarand, M.; Ustav, E.; Ustav, M. Genomic instability of the host cell induced by the human papillomavirus replication machinery. EMBO J. 2007, 26, 2180-2191. [CrossRef] [PubMed]

36. Clower, R.V.; Fisk, J.C.; Melendy, T. Papillomavirus E1 Protein Binds to and Stimulates Human Topoisomerase I. J. Virol. 2006, 80, 1584-1587. [CrossRef] [PubMed]

37. Loo, Y.-M.; Melendy, T. Recruitment of Replication Protein A by the Papillomavirus E1 Protein and Modulation by Single-Stranded DNA. J. Virol. 2004, 78, 1605-1615. [CrossRef]

38. Melendy, T.; Sedman, J.; Stenlund, A. Cellular factors required for papillomavirus DNA replication. J. Virol. 1995, 69, 7857-7867. [CrossRef]

39. Donaldson, M.; Mackintosh, L.J.; Bodily, J.; Dornan, E.S.; Laimins, L.A.; Morgan, I.M. An Interaction between Human Papillomavirus 16 E2 and TopBP1 Is Required for Optimum Viral DNA Replication and Episomal Genome Establishment. J. Virol. 2012, 86, 12806-12815. [CrossRef]

40. Bristol, M.L.; Wang, X.; Smith, N.W.; Son, M.P.; Evans, M.R.; Morgan, I.M. DNA Damage Reduces the Quality, but Not the Quantity of Human Papillomavirus 16 E1 and E2 DNA Replication. Viruses 2016, 8, 175. [CrossRef]

41. Gauson, E.J.; Donaldson, M.M.; Dornan, E.S.; Wang, X.; Bristol, M.; Bodily, J.M.; Morgan, I.M. Evidence supporting a role for TopBP1 and Brd4 in the initiation but not continuation of human papillomavirus 16 E1/E2 mediated DNA replication. J. Virol. 2015, 89, 17684-17699. [CrossRef] [PubMed] 
42. Duensing, S.; Munger, K. Centrosome abnormalities and genomic instability induced by human papillomavirus oncoproteins. Prog. Cell Cycle Res. 2003, 5, 383-391. [PubMed]

43. Duensing, S.; Munger, K. Human papillomaviruses and centrosome duplication errors: Modeling the origins of genomic instability. Oncogene 2002, 21, 6241-6248. [CrossRef] [PubMed]

44. Munger, K.; Basile, J.R.; Duensing, S.; Eichten, A.; González, S.; Grace, M.; Zacny, V.L. Biological activities and molecular targets of the human papillomavirus E7 oncoprotein. Oncogene 2001, 20, 7888-7898. [CrossRef] [PubMed]

45. Duensing, S.; Duensing, A.; Flores, E.R.; Do, A.; Lambert, P.F.; Munger, K. Centrosome Abnormalities and Genomic Instability by Episomal Expression of Human Papillomavirus Type 16 in Raft Cultures of Human Keratinocytes. J. Virol. 2001, 75, 7712-7716. [CrossRef]

46. James, C.D.; Fontan, C.T.; Otoa, R.; Das, D.; Prabhakar, A.T.; Wang, X.; Bristol, M.L.; Morgan, I.M. Human Papillomavirus 16 E6 and E7 Synergistically Repress Innate Immune Gene Transcription. mSphere 2020, 5. [CrossRef]

47. Evans, M.R.; James, C.D.; Bristol, M.L.; Nulton, T.J.; Wang, X.; Kaur, N.; White, E.A.; Windle, B.; Morgan, I.M. Human Papillomavirus 16 E2 Regulates Keratinocyte Gene Expression Relevant to Cancer and the Viral Life Cycle. J. Virol. 2019, 93, e01067-19. [CrossRef]

48. Evans, M.R.; James, C.D.; Loughran, O.; Nulton, T.J.; Wang, X.; Bristol, M.L.; Windle, B.; Morgan, I.M. An oral keratinocyte life cycle model identifies novel host genome regulation by human papillomavirus 16 relevant to HPV positive head and neck cancer. Oncotarget 2017, 8, 81892-81909. [CrossRef]

49. Wallace, N.A.; Khanal, S.; Robinson, K.L.; Wendel, S.O.; Messer, J.J.; Galloway, D.A. High Risk Alpha Papillomavirus Oncogenes Impair the Homologous Recombination Pathway. J. Virol. 2017, 91, e01084-17. [CrossRef]

50. Sakakibara, N.; Chen, D.; McBride, A.A. Papillomaviruses Use Recombination-Dependent Replication to Vegetatively Amplify Their Genomes in Differentiated Cells. PLoS Pathog. 2013, 9, e1003321. [CrossRef]

51. Anacker, D.C.; Moody, C. Modulation of the DNA damage response during the life cycle of human papillomaviruses. Virus Res. 2016, 231, 41-49. [CrossRef] [PubMed]

52. Chappell, W.H.; Gautam, D.; Ok, S.T.; Johnson, B.A.; Anacker, D.C.; Moody, C.A. Homologous Recombination Repair Factors Rad51 and BRCA1 Are Necessary for Productive Replication of Human Papillomavirus 31. J. Virol. 2015, 90, 2639-2652. [CrossRef] [PubMed]

53. Anacker, D.C.; Gautam, D.; Gillespie, K.A.; Chappell, W.H.; Moody, C.A. Productive Replication of Human Papillomavirus 31 Requires DNA Repair Factor Nbs1. J. Virol. 2014, 88, 8528-8544. [CrossRef] [PubMed]

54. Gillespie, K.A.; Mehta, K.P.; Laimins, L.A.; Moody, C.A. Human Papillomaviruses Recruit Cellular DNA Repair and Homologous Recombination Factors to Viral Replication Centers. J. Virol. 2012, 86, 9520-9526. [CrossRef] [PubMed]

55. Das, D.; Bristol, M.L.; Smith, N.W.; James, C.D.; Wang, X.; Pichierri, P.; Morgan, I.M. Werner Helicase Control of Human Papillomavirus 16 E1-E2 DNA Replication Is Regulated by SIRT1 Deacetylation. mBio 2019, 10, e00263-19. [CrossRef] [PubMed]

56. Das, D.; Smith, N.; Wang, X.; Morgan, I.M. The Deacetylase SIRT1 Regulates the Replication Properties of Human Papillomavirus 16 E1 and E2. J. Virol. 2017, 91, e00102-e00117. [CrossRef]

57. Boner, W.; Taylor, E.R.; Tsirimonaki, E.; Yamane, K.; Campo, M.; Morgan, I.M. A Functional Interaction between the Human Papillomavirus 16 Transcription/Replication Factor E2 and the DNA Damage Response Protein TopBP1. J. Biol. Chem. 2002, 277, 22297-22303. [CrossRef]

58. Moody, C.A.; Laimins, L.A. Human Papillomaviruses Activate the ATM DNA Damage Pathway for Viral Genome Amplification upon Differentiation. PLoS Pathog. 2009, 5, e1000605. [CrossRef]

59. Johnson, B.A.; Aloor, H.L.; Moody, C. The Rb binding domain of HPV31 E7 is required to maintain high levels of DNA repair factors in infected cells. Virology 2016, 500, 22-34. [CrossRef]

60. Blackford, A.N.; Jackson, S. ATM, ATR, and DNA-PK: The Trinity at the Heart of the DNA Damage Response. Mol. Cell 2017, 66, 801-817. [CrossRef]

61. Fischer, S.; Spychalowicz, A.; Wilk, G.; Śliwa, T.; Ludew, M.; Guzik, T.J. Pattern Recognition Receptors and Control of Innate Immunity: Role of Nucleic Acids. Curr. Pharm. Biotechnol. 2019, 19, 1203-1209. [CrossRef] [PubMed]

62. Motwani, M.; Pesiridis, S.; Fitzgerald, K.A. DNA sensing by the cGAS-STING pathway in health and disease. Nat. Rev. Genet. 2019, 20, 657-674. [CrossRef] [PubMed] 
63. Foley, J.F. Keeping cGAS under control. Sci. Signal. 2016, 9, ec78. [CrossRef]

64. Shu, C.; Li, X.; Li, P. The mechanism of double-stranded DNA sensing through the cGAS-STING pathway. Cytokine Growth Factor Rev. 2014, 25, 641-648. [CrossRef]

65. Lau, L.; Gray, E.E.; Brunette, R.L.; Stetson, D.B. DNA tumor virus oncogenes antagonize the cGAS-STING DNA-sensing pathway. Science 2015, 350, 568-571. [CrossRef]

66. Ronco, L.V.; Karpova, A.Y.; Vidal, M.; Howley, P. Human papillomavirus 16 E6 oncoprotein binds to interferon regulatory factor-3 and inhibits its transcriptional activity. Genome Res. 1998, 12, 2061-2072. [CrossRef]

67. Ivashkiv, L.B.; Donlin, L.T. Regulation of type I interferon responses. Nat. Rev. Immunol. 2013, 14, 36-49. [CrossRef]

68. Schoggins, J.W. Interferon-stimulated genes: Roles in viral pathogenesis. Curr. Opin. Virol. 2014, 6, 40-46. [CrossRef]

69. Schoggins, J.W.; MacDuff, N.A.; Imanaka, N.; Gainey, M.D.; Shrestha, B.; Eitson, J.L.; Mar, K.B.; Richardson, R.B.; Ratushny, A.V.; Litvak, V.; et al. Pan-viral specificity of IFN-induced genes reveals new roles for cGAS in innate immunity. Nature 2013, 505, 691-695. [CrossRef]

70. Au-Yeung, N.; Mandhana, R.; Horvath, C.M. Transcriptional regulation by STAT1 and STAT2 in the interferon JAK-STAT pathway. JAK-STAT 2013, 2, e23931. [CrossRef]

71. Fink, K.; Grandvaux, N. STAT2 and IRF9: Beyond ISGF3. JAK-STAT 2013, 2, e27521. [CrossRef]

72. Wang, W.; Yin, Y.; Xu, L.; Su, J.; Huang, F.; Wang, Y.; Boor, P.P.; Chen, K.; Cao, W.; Zhou, X.; et al. Unphosphorylated ISGF3 drives constitutive expression of interferon-stimulated genes to protect against viral infections. Sci. Signal. 2017, 10, eaah4248. [CrossRef] [PubMed]

73. Cheon, H.; Holvey-Bates, E.G.; Schoggins, J.W.; Forster, S.C.; Hertzog, P.J.; Imanaka, N.; Rice, C.M.; Jackson, M.W.; Junk, D.; Stark, G.R. IFN $\beta$-dependent increases in STAT1, STAT2, and IRF9 mediate resistance to viruses and DNA damage. EMBO J. 2013, 32, 2751-2763. [CrossRef] [PubMed]

74. Reiser, J.; Hurst, J.; Voges, M.; Krauss, P.; Münch, P.; Iftner, T.; Stubenrauch, F. High-Risk Human Papillomaviruses Repress Constitutive Kappa Interferon Transcription via E6 To Prevent Pathogen Recognition Receptor and Antiviral-Gene Expression. J. Virol. 2011, 85, 11372-11380. [CrossRef] [PubMed]

75. Castro-Muñoz, L.J.; Manzo-Merino, J.; Muñoz-Bello, J.O.; Olmedo-Nieva, L.; Cedro-Tanda, A.; Alfaro-Ruiz, L.A.; Hidalgo-Miranda, A.; Madrid-Marina, V.; Lizano, M. The Human Papillomavirus (HPV) E1 protein regulates the expression of cellular genes involved in immune response. Sci. Rep. 2019, 9, 13620. [CrossRef] [PubMed]

76. Li, S.; Labrecque, S.; Gauzzi, M.C.; Cuddihy, A.R.; Wong, A.H.; Pellegrini, S.; Matlashewski, G.J.; Koromilas, A.E. The human papilloma virus (HPV)-18 E6 oncoprotein physically associates with Tyk2 and impairs Jak-STAT activation by interferon- $\alpha$. Oncogene 1999, 18, 5727-5737. [CrossRef] [PubMed]

77. Hebner, C.; Beglin, M.; Laimins, L. Human Papillomavirus E6 Proteins Mediate Resistance to Interferon-Induced Growth Arrest through Inhibition of p53 Acetylation. J. Virol. 2007, 81, 12740-12747. [CrossRef]

78. Hong, S.; Cheng, S.; Iovane, A.; Laimins, L.A. STAT-5 Regulates Transcription of the Topoisomerase IIbeta-Binding Protein 1 (TopBP1) Gene To Activate the ATR Pathway and Promote Human Papillomavirus Replication. mBio 2015, 6, e02006-15. [CrossRef]

79. Hong, S.; Laimins, L. The JAK-STAT Transcriptional Regulator, STAT-5, Activates the ATM DNA Damage Pathway to Induce HPV 31 Genome Amplification upon Epithelial Differentiation. PLoS Pathog. 2013, 9, e1003295. [CrossRef]

80. Hong, S.; Mehta, K.P.; Laimins, L. Suppression of STAT-1 Expression by Human Papillomaviruses Is Necessary for Differentiation-Dependent Genome Amplification and Plasmid Maintenance. J. Virol. 2011, 85, 9486-9494. [CrossRef]

81. Terenzi, F.; Saikia, P.; Sen, G.C. Interferon-inducible protein, P56, inhibits HPV DNA replication by binding to the viral protein E1. EMBO J. 2008, 27, 3311-3321. [CrossRef] [PubMed]

82. Saikia, P.; Fensterl, V.; Sen, G.C. The Inhibitory Action of P56 on Select Functions of E1 Mediates Interferon's Effect on Human Papillomavirus DNA Replication. J. Virol. 2010, 84, 13036-13039. [CrossRef] [PubMed]

83. Scott, M.L.; Woodby, B.L.; Ulicny, J.; Raikhy, G.; Orr, A.W.; Songock, W.K.; Bodily, J. Human Papillomavirus 16 E5 Inhibits Interferon Signaling and Supports Episomal Viral Maintenance. J. Virol. 2019, 94. [CrossRef] [PubMed] 
84. Deshpande, R.A.; Lee, J.-H.; Arora, S.; Paull, T.T.; Aparicio, T.; Baer, R.; Gottesman, M.; Gautier, J.; Barton, O.; Naumann, S.C.; et al. Nbs1 Converts the Human Mre11/Rad50 Nuclease Complex into an Endo/Exonuclease Machine Specific for Protein-DNA Adducts. Mol. Cell 2016, 64, 593-606. [CrossRef]

85. Sartori, A.; Lukas, C.; Coates, J.; Mistrik, M.; Fu, S.; Bartek, J.; Baer, R.; Lukas, J.; Jackson, S. Human CtIP promotes DNA end resection. Nature 2007, 450, 509-514. [CrossRef]

86. Rein, K.; Stracker, T.H. The MRE11 complex: An important source of stress relief. Exp. Cell Res. 2014, 329, 162-169. [CrossRef]

87. Keijzers, G.; Liu, D.; Rasmussen, L.J. Exonuclease 1 and its versatile roles in DNA repair. Crit. Rev. Biochem. Mol. Biol. 2016, 51, 440-451. [CrossRef]

88. Pawlowska, E.; Szczepanska, J.; Blasiak, J. DNA2-An Important Player in DNA Damage Response or Just Another DNA Maintenance Protein? Int. J. Mol. Sci. 2017, 18, 1562. [CrossRef]

89. Bhat, K.; Cortez, D. RPA and RAD51: Fork reversal, fork protection, and genome stability. Nat. Struct. Mol. Biol. 2018, 25, 446-453. [CrossRef]

90. Jensen, R.B.; Carreira, A.; Kowalczykowski, S.C. Purified human BRCA2 stimulates RAD51-mediated recombination. Nature 2010, 467, 678-683. [CrossRef]

91. Kolinjivadi, A.M.; Sannino, V.; De Antoni, A.; Técher, H.; Baldi, G.; Costanzo, V. Moonlighting at replication forks - a new life for homologous recombination proteins BRCA1, BRCA2 and RAD51. FEBS Lett. 2017, 591, 1083-1100. [CrossRef] [PubMed]

92. Lee, J.H.; Paull, T.T. Direct activation of the atm protein kinase by the mre11/rad50/nbs1 complex. Science 2004, 304, 93-96. [CrossRef] [PubMed]

93. Kondo, T.; Kobayashi, J.; Saitoh, T.; Maruyama, K.; Ishii, K.J.; Barber, G.N.; Komatsu, K.; Akira, S.; Kawai, T. DNA damage sensor MRE11 recognizes cytosolic double-stranded DNA and induces type I interferon by regulating STING trafficking. Proc. Natl. Acad. Sci. USA 2013, 110, 2969-2974. [CrossRef] [PubMed]

94. Bhattacharya, S.; Srinivasan, K.; Abdisalaam, S.; Su, F.; Raj, P.; Dozmorov, I.; Mishra, R.; Wakeland, E.K.; Ghose, S.; Mukherjee, S.; et al. RAD51 interconnects between DNA replication, DNA repair and immunity. Nucleic Acids Res. 2017, 45, 4590-4605. [CrossRef]

95. Coggins, S.; Mahboubi, B.; Schinazi, R.; Kim, B. SAMHD1 Functions and Human Diseases. Viruses 2020, 12, 382. [CrossRef]

96. Gelais, C.S.; Kim, S.H.; Maksimova, V.V.; Buzovetsky, O.; Knecht, K.M.; Shepard, C.; Kim, B.; Xiong, Y.; Wu, L. A Cyclin-Binding Motif in Human SAMHD1 Is Required for Its HIV-1 Restriction, dNTPase Activity, Tetramer Formation, and Efficient Phosphorylation. J. Virol. 2018, 92, e01787-17. [CrossRef]

97. Simon, V.; Bloch, N.; Landau, N.R. Intrinsic host restrictions to HIV-1 and mechanisms of viral escape. Nat. Immunol. 2015, 16, 546-553. [CrossRef]

98. Ryoo, J.; Choi, J.; Oh, C.; Kim, S.; Seo, M.; Kim, S.-Y.; Seo, D.; Kim, J.; White, T.E.; Brandariz-Nuñez, A.; et al. The ribonuclease activity of SAMHD1 is required for HIV-1 restriction. Nat. Med. 2014, 20, 936-941. [CrossRef]

99. Beloglazova, N.; Flick, R.; Tchigvintsev, A.; Brown, G.; Popovic, A.; Nocek, B.; Yakunin, A.F. Nuclease Activity of the Human SAMHD1 Protein Implicated in the Aicardi-Goutières Syndrome and HIV-1 Restriction*. J. Biol. Chem. 2013, 288, 8101-8110. [CrossRef]

100. Gelais, C.S.; De Silva, S.; Amie, S.M.; Coleman, C.; Hoy, H.; Hollenbaugh, J.A.; Kim, B.; Wu, L. SAMHD1 restricts HIV-1 infection in dendritic cells (DCs) by dNTP depletion, but its expression in DCs and primary CD4+ T-lymphocytes cannot be upregulated by interferons. Retrovirology 2012, 9, 105. [CrossRef]

101. Goldstone, D.C.; Ennis-Adeniran, V.; Hedden, J.J.; Groom, H.C.T.; Rice, G.I.; Christodoulou, E.; Walker, P.A.; Kelly, G.; Haire, L.F.; Yap, M.W.; et al. HIV-1 restriction factor SAMHD1 is a deoxynucleoside triphosphate triphosphohydrolase. Nature 2011, 480, 379-382. [CrossRef] [PubMed]

102. Laguette, N.; Sobhian, B.; Casartelli, N.; Ringeard, M.; Chable-Bessia, C.; Ségéral, E.; Yatim, A.; Emiliani, S.; Schwartz, O.; Benkirane, M. SAMHD1 is the dendritic- and myeloid-cell-specific HIV-1 restriction factor counteracted by Vpx. Nature 2011, 474, 654-657. [CrossRef] [PubMed]

103. Tramentozzi, E.; Ferraro, P.; Hossain, M.; Stillman, B.; Bianchi, V.; Pontarin, G. The dNTP triphosphohydrolase activity of SAMHD1 persists during S-phase when the enzyme is phosphorylated at T592. Cell Cycle 2018, 17, 1102-1114. [CrossRef]

104. Coquel, F.; Neumayer, C.; Lin, Y.-L.; Pasero, P. SAMHD1 and the innate immune response to cytosolic DNA during DNA replication. Curr. Opin. Immunol. 2019, 56, 24-30. [CrossRef] 
105. Cabello-Lobato, M.J.; Wang, S.; Schmidt, C.K. SAMHD1 Sheds Moonlight on DNA Double-Strand Break Repair. Trends Genet. 2017, 33, 895-897. [CrossRef] [PubMed]

106. Daddacha, W.; Koyen, A.E.; Bastien, A.J.; Head, P.; Dhere, V.R.; Nabeta, G.N.; Connolly, E.C.; Werner, E.; Madden, M.Z.; Daly, M.B.; et al. SAMHD1 Promotes DNA End Resection to Facilitate DNA Repair by Homologous Recombination. Cell Rep. 2017, 20, 1921-1935. [CrossRef]

107. Kretschmer, S.; Wolf, C.; König, N.; Staroske, W.; Guck, J.; Häusler, M.; Luksch, H.; Nguyen, L.A.; Kim, B.; Alexopoulou, D.; et al. SAMHD1 prevents autoimmunity by maintaining genome stability. Ann. Rheum. Dis. 2014, 74, e17. [CrossRef]

108. Coquel, F.; Silva, M.-J.; Técher, H.; Zadorozhny, K.; Sharma, S.; Nieminuszczy, J.; Mettling, C.; Dardillac, E.; Barthe, A.; Schmitz, A.-L.; et al. SAMHD1 acts at stalled replication forks to prevent interferon induction. Nature 2018, 557, 57-61. [CrossRef]

109. Zhang, K.; Lv, D.-W.; Li, R. Conserved Herpesvirus Protein Kinases Target SAMHD1 to Facilitate Virus Replication. Cell Rep. 2019, 28, 449-459.e5. [CrossRef]

110. Kim, E.T.; Roche, K.L.; Kulej, K.; Spruce, L.A.; Seeholzer, S.H.; Coen, D.M.; Diaz-Griffero, F.; Murphy, E.A.; Weitzman, M.D. SAMHD1 Modulates Early Steps during Human Cytomegalovirus Infection by Limiting NF-kappaB Activation. Cell Rep. 2019, 28, 434-448.e6. [CrossRef]

111. Kim, E.T.; White, T.E.; Brandariz-Nuñez, A.; Diaz-Griffero, F.; Weitzman, M.D. SAMHD1 Restricts Herpes Simplex Virus 1 in Macrophages by Limiting DNA Replication. J. Virol. 2013, 87, 12949-12956. [CrossRef] [PubMed]

112. James, C.D.; Prabhakar, A.T.; Otoa, R.; Evans, M.R.; Wang, X.; Bristol, M.L.; Zhang, K.; Li, R.; Morgan, I.M. SAMHD1 Regulates Human Papillomavirus 16-Induced Cell Proliferation and Viral Replication during Differentiation of Keratinocytes. mSphere 2019, 4, e00448-19. [CrossRef] [PubMed]

113. Shamanna, R.A.; Croteau, D.L.; Lee, J.-H.; Bohr, V.A. Recent Advances in Understanding Werner Syndrome. F1000Research 2017, 6, 1779. [CrossRef] [PubMed]

114. Pichierri, P.; Ammazzalorso, F.; Bignami, M.; Franchitto, A. The Werner syndrome protein: Linking the replication checkpoint response to genome stability. Aging 2011, 3, 311-318. [CrossRef]

115. Lessel, D.; Saha, B.; Hisama, F.; Kaymakamzade, B.; Nurlu, G.; Gürsoy-Ozdemir, Y.; Thiele, H.; Nürnberg, P.; Martin, G.M.; Kubisch, C.; et al. Atypical Aicardi-Goutieres syndrome: Is the WRN locus a modifier? Am. J. Med. Genet. Part A 2014, 164, 2510-2513. [CrossRef]

116. Lee, S.-Y.; Lee, H.; Kim, E.-S.; Park, S.; Lee, J.; Ahn, B. WRN translocation from nucleolus to nucleoplasm is regulated by SIRT1 and required for DNA repair and the development of chemoresistance. Mutat. Res. Mol. Mech. Mutagen. 2015, 774, 40-48. [CrossRef]

117. Croteau, D.L.; Popuri, V.; Opresko, P.L.; Bohr, V.A. Human RecQ helicases in DNA repair, recombination, and replication. Annu. Rev. Biochem. 2014, 83, 519-552. [CrossRef]

118. Murfuni, I.; De Santis, A.; Federico, M.; Bignami, M.; Pichierri, P.; Franchitto, A. Perturbed replication induced genome wide or at common fragile sites is differently managed in the absence of WRN. Carcinog. 2012, 33, 1655-1663. [CrossRef]

119. Ammazzalorso, F.; Pirzio, L.M.; Bignami, M.; Franchitto, A.; Pichierri, P. ATR and ATM differently regulate WRN to prevent DSBs at stalled replication forks and promote replication fork recovery. EMBO J. 2010, 29, 3156-3169. [CrossRef]

120. Pirzio, L.M.; Pichierri, P.; Bignami, M.; Franchitto, A. Werner syndrome helicase activity is essential in maintaining fragile site stability. J. Cell Biol. 2008, 180, 305-314. [CrossRef]

121. Pichierri, P.; Franchitto, A.; Mosesso, P.; Palitti, F. Werner's Syndrome Protein Is Required for Correct Recovery after Replication Arrest and DNA Damage Induced in S-Phase of Cell Cycle. Mol. Biol. Cell 2001, 12, 2412-2421. [CrossRef] [PubMed]

122. Iannascoli, C.; Palermo, V.; Murfuni, I.; Franchitto, A.; Pichierri, P. The WRN exonuclease domain protects nascent strands from pathological MRE11/EXO1-dependent degradation. Nucleic Acids Res. 2015, 43, 9788-9803. [CrossRef] [PubMed] 
123. Palermo, V.; Rinalducci, S.; Sanchez, M.; Grillini, F.; Franchitto, A.; Pichierri, P. Way out/way in: How the relationship between WRN and CDK1 may change the fate of collapsed replication forks. Mol. Cell. Oncol. 2016, 4, e1268243. [CrossRef] [PubMed]

124. Palermo, V.; Rinalducci, S.; Sanchez, M.; Grillini, F.; Sommers, J.A.; Brosh, R.M.; Zolla, L.; Franchitto, A.; Pichierri, P. CDK1 phosphorylates WRN at collapsed replication forks. Nat. Commun. 2016, 7, 12880. [CrossRef] [PubMed]

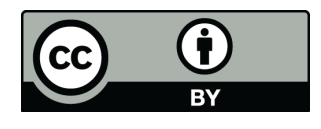

(C) 2020 by the authors. Licensee MDPI, Basel, Switzerland. This article is an open access article distributed under the terms and conditions of the Creative Commons Attribution (CC BY) license (http://creativecommons.org/licenses/by/4.0/). 